\title{
The Problems of Sustainable Development in a National Level
}

\author{
Ivars Brīvers \\ BA School of Business and Finance, Riga, Latvia \\ Jānis Sliece \\ Ventspils University College, Ventspils, Latvia
}

\begin{abstract}
The goal of the paper is to discuss the explanation of commonly accepted goal of economy in a national level and the problems which threaten the goal. Though the leading economists of the 20th century have strictly supported the necessity of close link between economics and morals, the mainstream economics mostly has regarded it as a problem of secondary importance. The paper discusses the deepest meaning of the generally accepted objective of economy - sustainable development, which necessarily should take into consideration the social dimension along with the economic and environmental. The different understandings of the wellbeing concept are considered and discussed, as it lies on the basis of the explanation of the goal—not any development, but development, which makes people happier. Next follows the discussion on the concepts of sustainability and its link with environment in a broader sense. It is followed by the discussion on the manipulations with human minds. The problem of the global and local economies is considered as a part of the discussion about the sustainability of economies of all levels. This leads to conclusions that social economics should be integrated in economic science as a substantial part. The idea of local economies is considered as an alternative to the present economic paradigm. The methodology of the conclusion making is based on qualitative historical analysis and empirical evaluation of the standpoints of the scientific discussion. The paper is mainly library-based. The ideas of world famous economists are taken from their own books in a printed form or that can be found in Internet. Conclusions are based on mainly qualitative comparison of the facts that arise from the theoretical discussion and empirical evidence of the study object manifestations in real life. Quantitative methods, briefly used, are basic econometrics - conventional correlation analysis, based on the statistic data of the World Bank. The scientific discussion has been approbated in students' audience in the study course of macroeconomics in BA School of Business and Finance, Riga, and Ventspils University College, and has been discussed in the fifth International Conference of Latvian Economic Association and Latvian Academy of Sciences.
\end{abstract}

Keywords: sustainable development, national economy, wellbeing, environment, morals, localization

\section{Introduction}

Though the leading economists of the 20th century, starting with Keynes (1972) and Schumpeter (1975),

\footnotetext{
Ivars Brīvers, Ph.D., professor of Economics, Department of Entrepreneurship and Business Informatics, BA School of Finance, Riga, Latvia.

Jānis Sliece, student of Business Administration, member of the Study Programme Council, Department of Economics and Business Administration, Ventspils University College, Ventspils, Latvia.

Correspondence concerning this article should be addressed to Ivars Brīvers, Hipokrata iela 19-8, LV-1079, Riga, Latvia. E-mail: abrivere@td.lv.
} 
have strictly supported the necessity of close link between economics and morals, the mainstream economics mostly has regarded it as a problem of secondary importance.

When the accumulation of wealth is no longer of high social importance, there will be great changes in the code of morals. We shall be able to rid ourselves of many of the pseudo-moral principles which have hag-ridden us for two hundred years, by which we have exalted some of the most distasteful of human qualities into the position of the highest virtues. (Keynes, 1972, pp. 321-334)

The goal of national economy is sustainable development. The concept of sustainable development has been defined in the Report of the World Commission on Environment and Development: Our Common Future- "development that meets the needs of the present without compromising the ability of future generations to meet their own needs" (World Commission on Environment and Development, 1987). This explanation has been used internationally, since the The United Nations Conference on Environment and Development in Rio de Janeiro in 1992. This definition is usually used by the World Bank, European Commission, and many other respectable sources. The importance and growth of sustainability and its connection to satisfaction of needs and wellbeing has been discussed further in the present work. The authors have tried to take a step towards the social economics in Walrasian sense-espousing justice as its guiding principle (Walras, 1969). Therefore, it contains synthesis of economic and philosophic though and its historical development.

\section{Sustainable Development and the Concept of Wellbeing}

Sustainability implies that the today's actions aimed to meet people's needs are not going to have a negative effect on the future generations. Development suggests constant growth. People's living conditions have to get better and better, in other words, the level of wellbeing has to grow. Is it possible for wellbeing to be constantly improved?

For the majority of the society, wellbeing is associated with material wealth. The same explanation is given in the Latvian Literary Language Dictionary (Latviešu literārās valodas vārdnīca): wellbeing-living conditions, material position that is characterised by wealth and material security (Letonika, 2011). Still material aspects are necessary, but not sufficient conditions for wellbeing. Only a happy person can live well. Daly (2008) in his article on steady state economy stated that correlation between absolute income and happiness extends only up to some threshold of "sufficiency". What is the definition of sufficiency? Sufficiency is a subjective psychological aspect that depends on the individual. Some authors, such as British researchers like Wilkinson and Pickett (2010) and Jackson (2009), asserted that economic growth does not largely contribute to society's happiness. Correlation between GDP (gross domestic product) per capita and happiness extends only up to certain level. Good example is United States of America, where society in general is relatively unhappy despite their success in economic indicators. A continuous material growth often has destructive consequences. A number of celebrities, which, due to their insufficient needs, are endlessly trying to earn more and more may serve as an example. They are publicized as paragon for the society and have a large influence on part of it, mainly the young generation. This creates a hole in the soul that they try to fulfill by using drugs. Therefore, authors believed that God - the moral absolute is needed to reach sufficiency. The most important is conviction that can be created only by this moral absolute. The influential German thinker Kant (1785) explained that good will is valuable apart from any consequences it brings about. Only people with true belief in God have this conviction that suppresses doubts. Is it just a coincidence that untraditionally 
thinking economists like Kārlis Balodis and Kenneth Ewart Boulding are closely related to religion? Maybe it allowed them to look at seemingly known concepts from a different point of view. Balodis is a theologian, a former Lutheran clergyman, and Boulding is a Quaker. Kant (1785) believed that morality is a spontaneous disposition and feeling. It is not an action that may be rewarded. It is a voluntary submission to an obligation (Kant, 1785). More importantly, act in a way that the maxim of your will may always serve as a general law (Kūle \& Kūlis, 1996). It is connected with another important aspect in relation to wellbeing in the socium. What can be learnt from identification with others and the posterity mentioned in the work of Boulding (1966)? A common morality is a prerequisite of actual wellbeing of the socium. It helps to create unity and reach common goals.

Jackson (2009) has carried out a research on what affects subjective wellbeing. In this research, $47 \%$ said that it is partner/spouse and family relationships, $24 \%$ said health, $8 \%$ said a nice place to live, $7 \%$ said money and financial situation, $5 \%$ said community and friends, $2 \%$ said work fulfillment, and $1 \%$ did not know/other. All of these factors substantially affect the quality of life. But having these aspects of life does not ensure a sense of fulfillment. Therefore, it is important to consider things in general and the base of this once again is an intangible metaphysical category - belief. A devoted Christian, who is often more satisfied with his or her life than a speculator eager to earn more and more money may serve as an example. Therefore, an individual may ensure a complete wellbeing only for himself and with the power of thoughts. Consequently, wellbeing is a constant condition without a tendency to grow.

Wellbeing is closely related to the feeling of happiness and happiness is the aim of human life. An unhappy person cannot have a good life. Only a person who reaches his or her goal is happy. These two words-wellbeing and happiness are closely related and should not be viewed separately. Wellbeing implies happiness and vice versa. There is a point to view them separately, only if wellbeing is thought of as an objective assessment and happiness - a subjective one. In order to look deeper in this issue, one should discuss what it means to live well and what happiness actually is. One cannot say about another person that he or she is living well judging by a house, a car, a beautiful spouse, lots of money, or a stable job alone. Only the person in question may assess that. It is essential for a person to feel happy, therefore these words should be viewed together. Nevertheless, the society tends to think that the level of wellbeing can be increased by, for example, receiving a bigger paycheck, in other words basing it on objective criteria. The truth is that no one knows whether the person's life, who has received a salary bonus, has improved by that. What if that person is not happy anyway? Apparently, his wellbeing has not been improved. Nevertheless, people will say that the salary bonus will allow the person to afford more or to repay debts. This indicates certain betterment, but it does not guarantee happiness and wellbeing. It is impossible to reach the state of wellbeing by merely collecting money. Actually, there is a connection between the two, but not too evident. The final outcome is misery that people with relatively high income and material security face.

People, who are aware of their happiness, will call themselves satisfied, but it will also serve as an objective assessment to people who are not actually happy. It means that a happy person will always call oneself satisfied, but a satisfied person will not always feel happy. Wellbeing is a constant state attained by an intense feeling of happiness. Therefore, satisfaction of needs that creates a fleeting feeling of happiness cannot be a basis for wellbeing. The concept of happiness is actually very complicated. There are also suggestions that happiness is not the aim of the person's life. It is supposedly not the most important thing (Šmids, 2008). Nevertheless happiness is indeed the main goal. 
What is referred to as happiness in a narrow meaning rather is the sudden satisfaction of needs and it is just a fleeting phenomenon. Any constant conditions cause only feeling of comfort that leaves the person indifferent. Human nature is such that it can derive intense enjoyment only from a contrast and very little from a state of things (Freud, 1930). Happiness comes from within and that belief in God helps to limit one's needs, making it possible to reach lasting happiness, which is also referred to as bliss. It is of utmost importance to understand that materialism may bring only fleeting happiness, what is needed to reach true happiness is improvement of spiritual health. The previously mentioned faith and conviction is the only way to last happiness. There are many surveys, where the basic question is satisfaction with life. The objectivity of such research is controversial, as the answer given by the respondent may reflect a fleeting feeling or be untrue. Happiness and satisfaction are not the same, for example, the previously mentioned person, who seemingly has "everything", is probably going to say that he or she is happy with life in a survey. But it does not prove that the person is actually happy. He or she simply understands the situation and seemingly appreciates what one has, nevertheless does not feel it emotionally. It is food for thought-what is really necessary to reach the aim of our life. God is a prerequisite to reach the aim-happiness, respectively wellbeing. Without this prerequisite, it is merely imitated satisfaction. A simple economy based on materialism, which does not reflect the true meaning of the word, will never be able to bestow wellbeing in its deepest meaning.

Uniformity created by absolute morality would help these people to satisfy their physiological needs and to get rid of one of the basic problems of economy — unlimited needs.

\section{Sustainability and Environment}

Today's events in politics show that sustainability is not a priority. In the majority of the world politicians, entrepreneurs and economists think that they will be able to act in the same vein forever or being aware of these problems hope that they are not going to affect them in their lifespan. These issues are the ever growing debt, pollution, migration, exhaustion of resources - the consequences of the existing economical paradigm. There is always the hope that somebody else will manage to deal with the previously mentioned difficulties. This could be linked to the aforementioned necessity of identification with the posterity. Today's events often make people think that they are trying to maximize their wellbeing at the expense of the future generations.

One of the main factors affecting the sustainability is the environment. It includes social, political, cultural, religious, ecological, ethical, and legal environment. These environments are largely reflected in Jackson's previously mentioned study of wellbeing (2009). People are aware of the need for these environmental aspects, but is it not being destroyed by their own hands? Often the environment is mentioned as important, but it is more of a formality. Economic growth causes irreversible negative consequences for a number of environmental aspects at the same time. Daly (2008) wrote in the previously mentioned article that economic growth increases environmental and social costs more than the benefits of increased production.

Social networks have crippled communication among people, which means that with every new generation, people have more and more difficulties in communicating verbally.

Pollution is the cause of insufficient clean air, but it also heightens the risk of diseases. A recently conducted research on Latvian TV about which is the best city to live in Latvia confirmed that the air quality is worse in the cities with better working conditions and more industrially-advanced, namely the leader in current emissions Riga, with Ventspils following as the second. 
The food in stores due to competition has lost its natural content. For a product to be stored longer, a variety of preservatives are used. Even products host their expiration date, are artificially restored, and are sold. With the aim of reducing production costs, natural ingredients are replaced with artificial ones, for example, nowadays it is impossible to find a meat product without the presence of an "interesting" liquid. It is a good business practice which results in higher profits. From this, it can be concluded that man creates dangerous and health-threatening environment for himself.

Today, relatively more people are suffering from mental illnesses, which is also a threat to the safety of the people around. The mental illness caused by mundane nervousness that occurs daily in a hurry is the pattern of bite style for modern man. Children are born with genetic problems that are clearly caused by polluted air, poor quality food, and global disasters. It is important to remember that people themselves are the cause of all those problems.

In fact, this is the fault of the economic system. These are largely short-term profit maximization consequences. Optimization, which is often the company's management, does not really objectively look at things until something tragic happens. But all these can be prevented by good governance. It is necessary to find new ways how to successfully manage the economic system.

Today's world can be characterized by global migration. People are looking for better living conditions or a happy place. What is the actual impact of migration? The interaction of people with diametrically different moral values may lead to chaos and mutual hatred. It is hard to imagine something that could cause bigger disorder than differences in religion and values. Sociums have become heterogeneous (Jaunzems, 2013). An example of such public disorder due to immigration is the disturbance that took place a few years ago in London, where immigrants constitute one third of the population in the summer of 2011-there were massacres in the city and explosions in the metro. These are the consequences of migration - a collision of moral values that undoubtedly affects sustainability.

The ever growing debt is a trend of developed countries. The 20 leading countries based on their GDP per capita are also on the list of the countries with the highest external debt as a percentage of GDP (World Bank, 2012). It can be viewed negatively from the perspective of sustainability and forces to view the world as a finance pyramid, where money is made from money. An example of this is the USA, which, when faced with default, increased its debt ceiling in order to avoid short-term difficulties. It is clear that this cannot go on forever and the default of such a powerful economy may lead to a global catastrophe, which according to this scenario is inevitable.

\section{Manipulations With the Human Minds}

People have an incessant connection to the mass media. In Latvia, the mass media helps the viewers to form an opinion on the present events with Hollywood movies and news presenting mostly one opinion. In these movies, the USA undoubtedly is demonstrating its good deeds to create a good image. It goes hand in hand with news reporting on how Americans are trying to bring world peace. The increase of the GDP is constantly showcased as an undoubted benefit by different graphic representations on how the situation in the state and the world has improved.

Democracy as an indubitable advantage has been questioned not only by the Ancient Greek philosophers; its flaws are clearly visible even to an everyday person of today. Attention should be paid to making group decisions in democracy via voting. A decision made by the majority affects everyone. But are the majority 
always right? The majority rarely make farsighted decisions, moreover if the voting is of a greater scale and involves all of the society, it is especially dangerous. The majority of the society do not have an education in jurisprudence, economics, or sociology. Politicians are duly taught that their target audience has the knowledge of the fifth grader. When making group decisions, rational individuals may come to an absurd and contradictory situation. Another aspect is division of power via creating politically advantageous coalitions, blatantly obvious today. Furthermore, in order to divide this power, individuals are trying to trick each other by using the most unattractive instruments (Jaunzems, 2013).

These manipulations remind of the famous work of Orwell (1946) where the author condemned the tyranny of communism in a form of political allegory. In this work, the author has described different methods of submission that allowed the pigs to relentlessly manipulate with other animals. One of these methods of submission was manipulation with figures, which is largely reminiscent of today's events. Argumentation based on the ignorance of the society has also been described in the aforementioned work. Thus the degradation of the society and the inability to think critically might be advantageous to the highest officials, as it makes it easier to manipulate with people. This can be supported by the fact that institutions of education are expressing a particular opinion that is considered to be the only truth—starting with Darwinism and ending with the standard economic theory.

\section{Localization of Economy}

The existing mainstream paradigm of economy, which is based on concentration of capital, financial markets, economic growth, and globalization, might have exhausted itself, because the aforementioned processes cause more bad than good. As an alternative, an opposite process has been suggested-localization. All of the previously mentioned economists - Daly (2008), Mill (1965), Jackson (2009), and Boulding (1966), stated a number of proposals restricting the existing paradigm in order to preserve the environment. Would it be beneficial for mankind to stop these growth processes? Undoubtedly, the theory of microeconomics defines the free market as an ideal economic system proving it with mathematical axioms. Any intervention of the country, for example, determination of the minimal wage and the ceiling of commodity prices, by imposition of taxes on products, creates a deadweight loss. Chang (2010) explained that the free market is just an illusion. This is true, as every country intervenes in its markets to a certain extent. But people do not notice restrictions on the market, as they are in accordance with their moral values. Any deviations are quickly noticed. All are aware of the fact that it is illegal to be engaged in trafficking of drugs and the selling of alcohol and arms is highly restricted. Recently, the government of Latvia has informed about a new draft law that would impose a ceiling on interest rates of fast credits.

Logically thinking, it is clear that if a tax will be introduced for advertising, demand in them would decrease. It means that employment in the sphere of marketing would decrease as well. Also, if social networks were banned to persons under the age of 18 in order to protect children and the youth, these networks would lose their income from advertising, causing damages. It is clear that by creating barriers to entrepreneurship, the unemployment is going to rise and the supply will decrease. If people did not buy these essentially unnecessary things, the companies selling them might experience financial difficulties. If the products were used for a longer period of time, the production capacity would decrease and there would be a lesser need for labor resources. Repair would increase the need for labor resources, but it would not outweigh the overall decrease of the level of employment. But how up until now the restrictions imposed by the state have been bypassed? 
Is it possible for a small self-sustainable economy to exist, if the created companies in that particular place already belong to foreign investors with an aim to export the manufactured products abroad? These investments are made only due to the relatively cheap workforce and developed infrastructure, therefore decreasing the expenses of resources. One example of this is Ventspils. Ventspils is basically dependent on transit business and foreign markets. Indeed, Latvians were forced to become dependent. Latvian entrepreneurs can no longer compete with huge foreign organizations, even the ones involved in food retail industry. Concentration of capital has created huge organizations affecting Latvia. The flow of free capital and financial markets drives huge resources from less wealthy countries to wealthy ones. It undoubtedly affects the potential of these countries, similarly as the global competition does not allow for small and local businesses to develop. Also the free movement of people has taken a lot of the enterprising and capable human resources. Majority of the 30 most successful businesses that are associated with Latvians do not belong to Latvians, for example, Cēsu alus, Kārums, Rīgas piensaimnieks, and not even Latvijas maiznieks. Latvians have become servants in their own country. Even this country does not belong to them anymore.

Of course, people could isolate themselves from the rest of the world and wisely cultivate protectionism, but then they have to be ready for a rise in poverty. Nevertheless, the increase of poverty might be only temporary.

\section{Conclusions}

The current processes may lead to ever growing global catastrophes even in the near future. The natural resources are being exhausted. The impact of these processes may be seen in the nature in the form of natural disasters. Is there a solution? Maybe small and local economies would force people to lead a more frugal lifestyle without a negative impact on the sustainability of the Earth. If people were able to achieve sufficiency, they would be happier with a smaller amount of material wealth than at this moment. The economy should be fully reconstructed basing the needs of the local people as the top priority. With the help of tax policy, all things that can endanger people and the environment should be eradicated. Detailed calculations should be made on the demand. Consequently, other spheres should be developed. Such a thorough reconstruction has to be researched in detail. It would also entail a requalification of labor resources on a large scale. This would be a dramatic change, but it is the only solution. Moral values have to be at the core of the society in order to realize common goals. That would be a new beginning for a sustainable development with a condition that localization would take place globally. Otherwise, some countries that have chosen the path of globalization will still be affected by global problems and catastrophes created as the result of the existing paradigms. Globalization that subjects the companies of small countries to global competition does not allow for their economies to thrive. A single currency and monetary policy does not let every country act according to its own needs. Mandatory reserves and currency issue are determined by an international organization; therefore, the country has no say in regard of its monetary policy. Treaties to enforce fiscal discipline etc. are aimed to submit the fiscal discipline of a country, including state budget, to one ideology. Nevertheless, if one takes into consideration that the situation of the member states is diametrically opposite, common policy is not an optimal solution. Such benefits as decrease of converting costs are outweighed by commission costs, but credit ratings and investments do not always leave a positive impact on the environment and the availability of the necessary resources. One-track thinking prevails that the higher interest rates the better, the higher availability of credits the better, the more people buy the better. At the core of this ideology is facilitation of economic development regardless 
of its sustainability, for example, the rise of immovable property prices is always seen as a positive sign. The reason for the increase of prices is usually the increase of demand. Due to the market activation, the average income level increases. The price of property increases by several times, making it a success story for the owners of immovable property, but there are also victims in this scenario - people who do not speculate but are working and cannot afford to rent a flat. That was also the case in the years of plenty. By indexing pensions and increasing tariffs, the economy grows as well, but the actual level of income stays the same.

People have to act right now. To talk about the future is useful, only if it leads to action now (Schumacher, 1973).

\section{References}

Boulding, K. E. (1966). The economics of the coming spaceship earth. In H. Jarret (Ed.), Environmental quality in a growing economy, essays from the 6th RFP Forum (pp. 3-14). Baltimore, MD: Johns Hopkins University Press.

Chang, H. J. (2010). 23 things they don't tell you about capitalism. London: Penguine Books Ltd.

Daly, H. (2008). A steady-state economy. Retrieved from www.sd-commission.org.uk/publications.php?id=775

Freud, S. (1930). Das Unbehagen in der Kultur (Civilization and its discontents). Wien: Internationaler psychoanalytischer Verlag.

Jackson, T. (2009). Prosperity without growth: Economics for a finite planet. London: Routledge.

Jaunzems, A. (2013). Asimetriskā informācija un Errou teorēma mikroekonomikā (Asymmetric information and Arrow theorem in microeconomics).

Retrieved

from

http://www.lza.lv/LZA_VestisA/66_4/2_Andrejs\%20Jaundzems\%20ASEMERTISKA\%20INFORMACIJA.pdf

Kant, I. (1785). Grundlegung zur Metaphysik der Sitten (Fundamental principles of the metaphysic of morals). Retrieved from http://www.gutenberg.org/cache/epub/5682/pg5682.html

Keynes, J. M. (1972). Economic possibilities for our grandchildren. In D. Moggeridge (Ed.), The collected writings of John Maynard Keynes (pp. 321-334). London: Macmillan.

Kūle, M., \& Kūlis, R. (1996). Filosofija (Philosophy). Rīga: Apgāds Burtnieks.

Letonika. (2011). Latviešu literārās valodas vārdnīca (Latvian Literary Dictionary). Retrieved from http://www.tezaurs.lv/llvv/

Mill, J. S. (1965). Principles of political economy. New York: A. M. Kelley.

Orwell, G. (1946). Animal farm. New York: Brace and Company.

Schumacher, E. F. (1973). Small is beautiful: Economics as if people mattered. London: Blond \& Briggs.

Schumpeter, J. A. (1975). Capitalism, socialism and democracy. New York: Harper.

Šmids, V. (2008). Laime. Viss, kas jums par laimi jāzina, un kāpēc tā dzīvē nav vissvarīgākais (Happiness. Everything you should know about it, and why it is not the most important thing in the life). Rìga: Zvaigzne ABC.

Walras, L. (1969). Elements of pure economics. New York: A. M. Kelley.

Wilkinson, R. G., \& Pickett, K. (2010). The spirit level: Why greater equality makes societies stronger. New York: Bloomsbury Press.

World Bank. (2012). Data. Retrieved from http://data.worldbank.org/indicator/NY.GDP.PCAP.CD?order=wbapi_ data_value_2012+wbapi_data_value+wbapi_data_value-last\&sort=desc

World Commission on Environment and Development. (1987). Our common future. Oxford: Oxford University Press. 